Article

\title{
A New Zealand Perspective on Hydrogen as an Export Commodity: Timing of Market Development and an Energy Assessment of Hydrogen Carriers
}

\author{
James T. Hinkley
}

check for updates

Citation: Hinkley, J.T. A New Zealand Perspective on Hydrogen as an Export Commodity: Timing of Market Development and an Energy Assessment of Hydrogen Carriers. Energies 2021, 14, 4876. https:// doi.org/10.3390/en14164876

Academic Editor: Nader Karimi

Received: 9 July 2021

Accepted: 5 August 2021

Published: 10 August 2021

Publisher's Note: MDPI stays neutral with regard to jurisdictional claims in published maps and institutional affiliations.

Copyright: (C) 2021 by the author. Licensee MDPI, Basel, Switzerland. This article is an open access article distributed under the terms and conditions of the Creative Commons Attribution (CC BY) license (https:// creativecommons.org/licenses/by/ $4.0 /)$.
Sustainable Energy Systems, School of Engineering and Computer Science, Victoria University of Wellington, Wellington 6140, New Zealand; jim.hinkley@vuw.ac.nz

\begin{abstract}
Hydrogen is currently receiving significant attention and investment as a key enabler of defossilised global energy systems. Many believe this will eventually result in the international trade of hydrogen as a commodity from countries with significant renewable energy resources, for example New Zealand and Australia, to net energy importing countries including Japan and Korea. Japan has, since 2014, been actively exploring the components of the necessary supply chains, including the assessment of different hydrogen carriers. Public/private partnerships have invested in demonstration projects to assess the comparative merits of liquid hydrogen, ammonia, and organic carriers. On the supply side, significant projects have been proposed in Australia while the impending closure of New Zealand's Tiwai Point aluminium smelter at the end of 2024 may provide an opportunity for green hydrogen production. However, it is also evident that the transition to a hydrogen economy will take some years and confidence around the timing of supply and demand capacity is essential for new energy infrastructure investment. This paper reviews the expected development of an export market to Japan and concludes that large scale imports are unlikely before the late 2020s. Comparative evaluation of the energy efficiency of various hydrogen carriers concludes that it is too early to call a winner, but that ammonia has key advantages as a fungible commodity today, while liquid hydrogen has the potential to be a more efficient energy carrier. Ultimately it will be the delivered cost of hydrogen that will determine which carriers are used, and while energy efficiency is a key metric, there are other considerations such as infrastructure availability, and capital and operating costs.
\end{abstract}

Keywords: hydrogen; export; carriers; ammonia; $\mathrm{MCH}$; renewable

\section{Introduction \\ The Case for Hydrogen}

Despite growing concerns over climate change, global energy supply remains dominated by fossil fuels, with coal, oil, and natural gas supplying approximately $84 \%$ of primary energy demand in 2019 [1]. Hydrogen is seen by many as an important part of the future energy landscape, with expectations of a transition to a hydrogen economy at some point in the future. It has the ability and flexibility to generate heat, electricity, and motive power without emissions at the point of use. However, hydrogen is not a fuel in the normal sense but is an energy vector as it cannot be mined or extracted from the earth in the way conventional fuels are. It is currently produced from hydrocarbon fuels in huge volumes, but this results in globally significant $\mathrm{CO}_{2}$ emissions. Decarbonising energy systems with hydrogen will require production from renewable energy through electrolysis or other routes such as thermochemical and photoelectrochemical processes.

The timing of this transition has proven difficult to forecast [2], although recent years have seen significant momentum building and key publications released such as the IEA's report Future of Hydrogen, prepared for the G20 summit in 2019 [3]. Hydrogen is already 
seen as a key energy source for energy poor but industrially developed and energy intensive countries such as Japan and Korea, which have both published future energy strategies in which today's imports of coal and LNG are supplanted by hydrogen $[4,5]$. Longer term goals include being able to economically source green hydrogen from renewable energy rich countries. New Zealand is one of many potential providers of this green hydrogen, but considerable uncertainty remains around the timing and the implementation of such a supply chain. The Japanese Government has supported the evaluation of different hydrogen carriers through its Strategic Innovation Promotion (SIP) program, with ammonia, liquid hydrogen (LH2), and methyl cyclohexane $(\mathrm{MCH})$ being explored as potential options [6].

The New Zealand Government recently enacted the Climate Change Response (Zero Carbon) Amendment Bill, which is intended to "provide a framework by which New Zealand can develop and implement clear and stable climate change policies" [7]. The Government aims to achieve a net zero carbon economy by 2050. This ambitious goal requires the transition away from an energy system that relies heavily on hydrocarbons (oil, coal, and gas) to one that is based on renewable energy sources. Hydrogen has been identified as a key potential enabler of this transition, and a potential export opportunity. This was explored in a Green Paper in 2019, which observed that "While hydrogen produced from fossil fuels and industrial processes (brown, blue and grey) may play a role in the transition of New Zealand's regions and existing industries, the Government considers there is greater opportunity for New Zealand in exploring the use of our renewable energy to produce green hydrogen as an alternative fuel for domestic use and for export" [8]. There are already a number of hydrogen projects underway, including:

- An electrolyser and refuelling station at the Port of Auckland, which has plans to be a zero emissions port by 2040 [9]

- A partnership between Tuaropaki Trust and Obiyashi Corporation to demonstrate hydrogen production from geothermal electricity [10]

- Development of a refuelling network for the heavy vehicle market, and supply of left hand drive trucks from Hyzon [11]

- A partnership between Hiringa Energy and Ballance Agrinutrients to produce green ammonia from wind power derived hydrogen [12]

- Contact Energy and Meridian, two of the major electricity generators and retailers, have recently called for registrations of interest to develop the world's largest green hydrogen plant. This is based on redirecting the approximately $600 \mathrm{MW}$ of high capacity factor generation that currently supplies the aluminium smelter at Tiwai Point, due to close at the end of $2024[13,14]$

Developing supply chains at the required scale for an export market will require substantial investment in long term assets, and such investment is difficult in the absence of supply agreements. This article explores two key aspects: at what stage is the market likely to materialise and what might it look like in terms of price and volume; and what are the pros and cons of the different hydrogen carriers across the supply chain from renewable energy to the end user. We explore these questions from the point of view of key stakeholders in industry and government in New Zealand-referred to colloquially as NZ Inc.-in the context of export trade opportunities. A rational and realistic understanding of the potential markets and likely carriers is regarded essential to ensure that opportunities are properly understood and a staged transition to a new export energy market is enabled and facilitated.

In this paper, we review available data for the projected demand for hydrogen in Japan, one of the most advanced countries in terms of developing a hydrogen economy. We also explore the characteristics and energy requirements of the most prominent hydrogen carriers to better understand how the market may evolve and what the implications may be for the exporting country. 


\section{Development of Hydrogen Demand in Japan}

\subsection{Fourth Strategic Energy Plan and the Anticipated Role of Hydrogen}

Japan has identified hydrogen as a critical component of its energy system for some years, and this was formally adopted in the energy strategy released in 2014. After the Fukushima disaster, the government established the fourth Strategic Energy Plan for 2030, which sought to reduce reliance on both nuclear and fossil fuels and expand renewable energy. The Agency for Natural Resources and Energy, METI, published a summary of the strategy in English, which articulated the three broad areas of activity and investment across a multi-decadal time frame, as shown in Figure 1 [15].
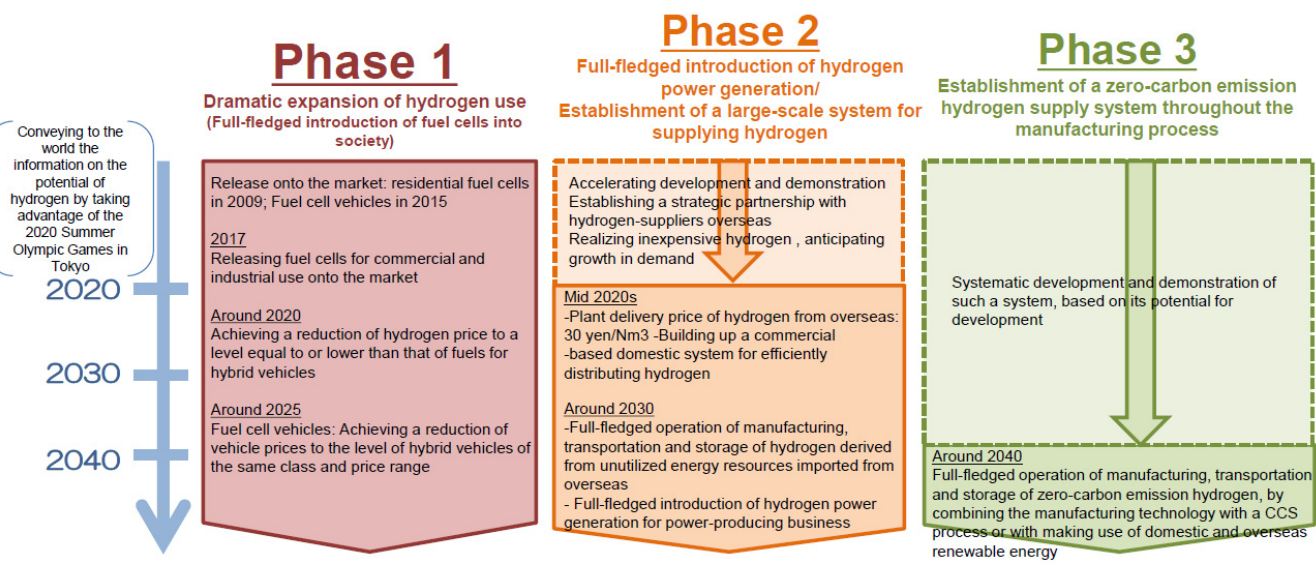

Figure 1. Summary of the strategic road map for hydrogen and fuel cells (redrawn, from METI [15]).

Phase 1 activities built on existing programmes and concentrated on developing hydrogen fuel cell applications including domestic units for combined heat and power and fuel cell vehicles. In 2016, METI published targets for deployment, including "about 40 thousand vehicles by 2020, about 200 thousand vehicles by 2025, and about 800 thousand vehicles by 2030, in total" and for hydrogen fuelling stations ("About 160 stations by 2020 and about 320 stations by $\left.2025^{\prime \prime}\right)$.

Phase 2 activities were intended to identify and demonstrate the technologies needed for thermal power generation from hydrogen and to enable the establishment of supply chains from overseas countries to Japan. A target for a delivered price of 30 yen per $\mathrm{Nm}^{3}$ of hydrogen from around 2025 was established, about $\$ 0.25 \mathrm{US} / \mathrm{Nm}^{3}$ or $\$ 2.80 \mathrm{US} / \mathrm{kg}$ based on exchange rates at the end of 2014. Phase 2 included support for ammonia and hydrogen combustion tests in gas turbines [16] as well as the comparative evaluationand demonstration — of three hydrogen carriers under the SIP program. These carriers will be discussed in detail in the next section, with an examination of the energy inputs required for synthesis and decomposition for release of hydrogen, to understand the nature and location of the energy penalties and opportunities for the exporting and importing parties. It is perhaps worth noting also that the initial focus is on supply chain development rather than on emissions free hydrogen from purely renewable energy. Two demonstration projects are being developed based on natural gas reforming in Brunei and brown coal gasification in Australia's Latrobe Valley $[17,18]$. Fully fledged operation of the supply chains, distribution systems, and thermal power generation was anticipated by 2030 .

Phase 3 of the strategy is a longer-term goal to establish a zero-carbon emission hydrogen supply system throughout the manufacturing process built on sustained development and evaluation of the components. It was expected that fully fledged zero-carbon supply chains based on production from fossil fuels together with carbon capture and sequestration (CCS) or production from renewable energy would be in place by around 2040 . The transition to hydrogen fired thermal power generation is contingent on economics as well as technology. In METI's summary of the Basic Hydrogen Strategy [19], it is noted that "In the future, Japan will attempt to make hydrogen power generation including 
environmental values as cost competitive as LNG power generation. To this end, Japan's annual hydrogen procurement may have to be 5-10 million tons (amounting to 15-30 GW in power generation capacity)".

\subsection{Forecasts of Demand Growth for Hydrogen in Japan}

The Japanese strategy includes the progressive development of hydrogen applications from small scale distributed fuel cells (DFC) in houses (Ene-Farm) and vehicles to the substitution of hydrogen for LNG in thermal power stations. The expected initial demand is therefore expected to show steady growth that parallels the expected deployment of DFC and fuel cell vehicles (FCV), with a significant increase in demand expected at some stage after 2030 when thermal power stations switch to hydrogen. Before reviewing literature summaries of the expected demand, it is worth understanding the magnitude of the demand for different applications. As seen in Table 1, the hydrogen demand from mobile applications such as FC vehicles is likely to be rather limited by 2030, and that the early demand for hydrogen could be in fuel switching of the Ene-Farm DFC fleet from natural gas to hydrogen. METI [19] have indicated that the expected total demand for 2030 is 300,000 tonnes. This implies that natural gas will remain the main fuel for residential DFC, which is unsurprising due to the infrastructure requirements for widespread hydrogen reticulation.

Table 1. Estimated potential demand for hydrogen for selected fuel cell applications.

\begin{tabular}{cccc}
\hline Application & Consumption [20] & $\begin{array}{c}\text { 2030 Targets } \\
\text { Vehicles/Units [19] }\end{array}$ & Demand (tpa) \\
\hline FC Bus & $4600 \mathrm{~kg} /$ year & 1200 & 5520 \\
FCV & $94 \mathrm{~kg} /$ year & 800,000 & 78,400 \\
Ene-Farm $^{1}$ & $201 \mathrm{~kg} /$ year & $53,000,000$ & $1,065,300$ \\
1 GW thermal PS ${ }^{2}$ & $300,000,000 \mathrm{~kg} /$ year & $\mathrm{N} / \mathrm{A}$ & \\
\hline
\end{tabular}

${ }^{1}$ Ene-Farm units operate with an on-board reformer that converts methane to hydrogen. ${ }^{2}$ While there is no 2030 target for thermal power stations, the long-term goal is to make hydrogen generation competitive with LNG. The demand for a $1 \mathrm{GW}$ power station is estimated from [19].

It is also clear that there is a considerable existing capacity for hydrogen production within Japan, albeit from fossil sources. Mitsui Global Strategic Studies Institute estimated that "existing industries have spare capacity or by-product to supply additional 778,000 ton hydrogen [per year], which corresponds to fuel for 830,000 FCVs, [and] means that even [if] the FCV target in $2030(800,000$ FCVs) is achieved, still the whole demand of hydrogen fuel could be supplied domestically" [20].

The prospective demand for hydrogen was recently explored [21] to establish a trading link between Patagonia and Japan (Figure 2). While the 2017 Ishimoto reference does not seem to contain the reported data, an earlier paper by the same author [22] indicated that initial demand would be due to stationary fuel cells for combined heat and power (CHP), with transport becoming significant after 2030 and power generation from about 2045.

In summary, while there is naturally considerable uncertainty about future demand, it is unlikely that the requirement for large scale hydrogen importation will be a reality until some time after 2030 and is likely to be associated with the intended fuel switching of thermal power generation from LNG to hydrogen. The delivered price of hydrogen has been set at 30 yen $/ \mathrm{Nm}^{3}$ or about $\$ 2.80 \mathrm{US} / \mathrm{kg}$. It is not clear if this price is anchored to a particular year, or if the figure remains fixed and effectively devalues with time. 


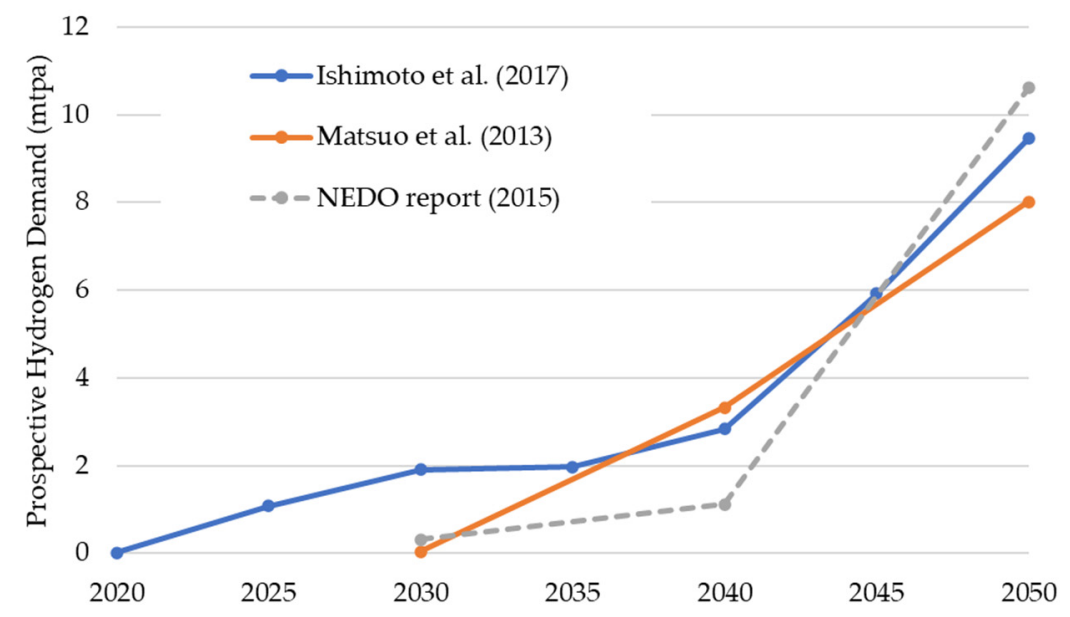

Figure 2. Projected growth in Japanese hydrogen demand according to several studies (after [21]).

\section{Methodology Used to Evaluate Energy Considerations of Supply Chains}

The SIP programme considers three potential hydrogen carriers. Some of the key properties relevant to energy flows are summarised below (Table 2).

Table 2. Properties and characteristics of the prominent potential hydrogen carriers [23-26].

\begin{tabular}{cccc}
\hline Property & Liquid $\mathbf{H}_{\mathbf{2}}$ & Ammonia, $\mathbf{N H}_{\mathbf{3}}$ & MCH \\
\hline Boiling point $\left({ }^{\circ} \mathrm{C}\right)$ & -252.9 & -33.3 & 101 \\
\hline Hydrogen density $(\mathrm{wt} \%)$ & 100 & 17.8 & 6.16 \\
\hline Hydrogen density $\left(\mathrm{kg} / \mathrm{m}^{3}\right)$ & 70.9 & 121 & 47.1 \\
\hline $\mathrm{H}_{2}$ release temp. $\left({ }^{\circ} \mathrm{C}\right)$ & -252.9 & $350-900$ & $200-400$ \\
\hline Regeneration temp. $\left({ }^{\circ} \mathrm{C}\right)$ & $\mathrm{N} / \mathrm{A}$ & $400-600$ & $100-200$ \\
\hline $\begin{array}{c}\mathrm{H}_{2} \text { release enthalpy change } \\
\left(\mathrm{kJ} / \mathrm{molH}_{2}\right)\end{array}$ & 0.899 & 30.6 & 67.5 \\
\hline $\begin{array}{c}\text { Lower heating value, } \mathrm{LHV} \\
(\mathrm{MJ} / \mathrm{kg})\end{array}$ & 120 & 18.6 & $\mathrm{~N} / \mathrm{A}$ \\
\hline $\begin{array}{c}\text { Other properties } \\
\text { Explosive, cryogenic liquid }\end{array}$ & $\begin{array}{c}\text { Acute toxicity, } \\
\text { Corrosive }\end{array}$ & $\begin{array}{c}\text { Flammable, } \\
\text { Irritant }\end{array}$ \\
\hline
\end{tabular}

\subsection{Energy Balance Methodology}

In the following discussion, we consider the flows of energy along the supply chain, including the following:

- Electricity required for electrolysis (but excluding transmission and distribution losses).

- Energy required for formation of the liquid carrier (electrical or thermal). Discussed on a per-carrier basis. While the formation and dissociation reactions are in principle reversible, thermal management is important as the reactions are carried out at elevated temperatures.

- Energy required for transport of the carrier from New Zealand to Japan (assumed to be from Bluff to Yokohama). The distance between ports was estimated at $6143 \mathrm{~nm}$ with an estimated time at sea of 17.1 days (using the tool at http:/ / ports.com/sea-route/, accessed on 18 June 2021). An average speed of 15 knots speed was assumed based on values for oil and chemical tankers (https:/ / www.marineinsight.com/guidelines/ speed-of-a-ship-at-sea /, accessed on 18 June 2021). Note that in the case of the LH2 vessel, the boil off is used as fuel for propulsion. It is further assumed that the other carriers must be transported using green fuels, to ensure the integrity of the delivered hydrogen as a green fuel. The energy demand for shipping is added to the supply 
chain to that point (effectively assuming that the carrier is the most energy efficient renewable fuel at that point).

- Energy required to release the hydrogen from the carrier. Note that the end use for the hydrogen has a significant impact on this step. For example, if ammonia can be used directly in solid oxide fuel cells or in gas turbines, then there is no need to dissociate the ammonia. However, if the end use is for FCV then strict quality constraints will apply as traces of ammonia can poison fuel cell catalysts, and the hydrogen needs to be compressed to appropriate pressures for onboard storage. This is discussed in greater detail in the next section.

\subsection{Electrical Energy Required for Electrolysis}

For the purposes of this article the energy required for production of hydrogen from electrolysis will be assumed to be the same for all carriers, based on an efficiency of $70 \%$ or a consumption of $47.6 \mathrm{kWh} / \mathrm{kg}$ of hydrogen produced [27,28]. This is based on PEM electrolysis for coupling with variable renewable energy; it is possible that if a facility were established at Tiwai Point that alkaline electrolysis could be used with slightly lower power consumption.

\section{Data and Analysis of Individual Carriers}

\subsection{Liquid Hydrogen (LH2)}

Liquid hydrogen is conceptually the simplest of the carriers as no chemical transformation is required for synthesis or decomposition. However, the exceptionally low boiling point of hydrogen means that considerable energy must be expended in the liquefaction process. Hydrogen liquefaction is also relatively inefficient; while the thermodynamic limit is around $3.9 \mathrm{kWh} / \mathrm{kg}$ [29], in reality liquefaction work is only $20-35 \%$ efficient and even the best plants reportedly consume around $10 \mathrm{kWh} / \mathrm{kg}$, with mostly higher values reported (Table 3). For the purposes of this study, we will assume an electrical energy demand of $10 \mathrm{kWh} / \mathrm{kg}$, which sits between current practice and projected demands in the future. This indicates an energy consumption of $57.6 \mathrm{kWh} / \mathrm{kg}$ of liquid hydrogen, and a LHV RE to hydrogen energy efficiency of $57.8 \%$.

Table 3. Selected current and projected energy requirements for hydrogen liquefaction in $\mathrm{kWh} / \mathrm{kg}$.

\begin{tabular}{ccc}
\hline Reference & Current Consumption & Future \\
\hline Krasae-in et al., 2010 [30] & 10 to 15 & 5 (target) \\
Watanabe et al., 2010 [31] & 13.4 & 6.7 \\
Ohlig and Decker, 2014 [32] & 11.9 & 6 (target) \\
Kamiya et al., 2015 [29] & 11.1 & \\
Cardella et al., 2017 [33] & 12.5 to 15 & $5.9-6.6$ (model) \\
Heuser et al., 2019 [21] & 12 to 15 & $6.78^{1}$ \\
\hline
\end{tabular}

${ }^{1}$ Future energy demand based on the 2008 Nexant report [34] and the 2013 IdealHy study [35].

Shipping of liquid hydrogen is challenging due to boil off-because the liquid is so cold it is difficult to prevent some absorption of energy from the environment even with specially constructed and insulated tankers. Kawasaki heavy industries have developed a design for a large scale 160,000 $\mathrm{m}^{3}$ hydrogen carrier with four spherical tank units with vacuum panel walls [29]. The tanks are expected to have a boil off rate of $0.2 \%$ per day or less, with this evaporation gas used as fuel for the vessel in a hydrogen gas engine. Kawasaki has already launched a smaller prototype vessel with a capacity of $1250 \mathrm{~m}^{3}$ of liquid hydrogen and a sea speed of approximately 13 knots [36]. Existing LPG carriers suitable for ammonia would have a capacity of $85,000 \mathrm{~m}^{3}$ by comparison [37], while conventional oil takers could be used for transport of $\mathrm{MCH}$ [23]. 
As noted above, we have assumed a slightly higher average vessel speed of 15 knots for the tankers giving a transit time at sea of 17.1 days. If the boil off rate is $0.2 \%$ per day, the total boil off can be estimated using the equation:

$$
\text { Liquid } \mathrm{H}_{2} \text { remaining }=(1-\text { daily boil off })^{\text {days at sea }} \text {, or }(1-0.002)^{17.1}=0.9663 \text {, }
$$

indicating that just under $3.4 \%$ of the initial cargo is lost due to boil off in transit. This equates to about 382 tonnes out of an initial cargo of 11,340 tonnes. We assume that this hydrogen is sufficient to provide all the energy required for vessel propulsion. In energy terms, this equates to $45,800 \mathrm{GJ}$ based on the LHV of hydrogen (120 GJ/tonne) or $0.35 \mathrm{MJ} / \mathrm{tkm}$. While this is higher than IEA's reported energy intensity for global shipping of $0.08 \mathrm{MJ} / \mathrm{tkm}$ for 2020 [38], this is perhaps unsurprising as liquid hydrogen is a relatively low density cargo at $71 \mathrm{~kg} / \mathrm{m}^{3}$.

It is assumed that there is minimal energy required at the import terminal to convert the liquid hydrogen to the form required by the final application. This is possibly simplistic, as there will certainly be some energy demands to operate the terminal. However, it may also be possible to use the enthalpy change from hydrogen evaporation and recover some of the energy of compression and liquefaction. While this has been investigated for recovery of "waste cold" energy from LNG $[39,40]$, the systems for hydrogen require further development and improvement [23]. Options include electricity generation using a Brayton cycle gas turbine [41] and integration with solid oxide fuel cells to maximise the exergetic efficiency of both systems [23]. This may lead to additional value for Japan from the import of LH2. The amount of energy that could be extracted will be limited to the thermodynamic work of liquefaction of around $3.9 \mathrm{kWh} / \mathrm{kg}$ of hydrogen, although the low cold side temperature means that the Carnot efficiency is relatively high, and efficiencies of up to $72 \%$ may be possible with a Brayton cycle [23]. This could potentially result in an additional $2.8 \mathrm{kWh} / \mathrm{kg}$ of electricity generation from regasification of LH2.

The energy requirements for 1 tonne of hydrogen delivered to Yokohama by LH2 vessel can be estimated as $59.6 \mathrm{kWh} / \mathrm{kg}(57.6 / 0.9663)$. The boiled off hydrogen used as fuel for vessel propulsion is $2.01 \mathrm{kWh} / \mathrm{kg}$ delivered, as the additional hydrogen must be produced at the same efficiency as the LH2. The LHV of hydrogen is $120 \mathrm{MJ} / \mathrm{kg}$ or $33.33 \mathrm{kWh} / \mathrm{kg}$, implying an energy efficiency of $55.9 \%$ from RE to delivered hydrogen energy, with potential for further energy recovery from gasification of the LH2. The energy efficiency of the different steps along the supply chain is summarised in Table 4.

Table 4. Summary of energy efficiency for the various stages in a liquid hydrogen supply chain.

\begin{tabular}{|c|c|c|c|}
\hline Step & LHV Efficiency & $\begin{array}{c}\text { Energy Intensity, } \\
\mathrm{kWh} / \mathrm{kg} \mathrm{H} \mathrm{H}_{2}\end{array}$ & $\begin{array}{l}\text { Retained Energy, } \\
\text { LHV (MWh) }\end{array}$ \\
\hline Generation & & & 100 \\
\hline Electrolysis & $70.0 \%$ & 47.6 & 70 \\
\hline Formation & $82.7 \%$ & 10.0 & 57.9 \\
\hline Shipping & $96.6 \%$ & 2.0 & 55.9 \\
\hline Release ${ }^{1}$ & $104.9 \%$ & -2.8 & 58.7 \\
\hline Total & $58.5 \%$ & 56.8 & \\
\hline LHV (kWh/kg) & & 33.3 & \\
\hline
\end{tabular}

${ }^{1}$ Hypothetical power generation from gasification of LH2; if this is not practical the overall LHV efficiency is $~ 55.9 \%$.

\subsection{Ammonia}

Ammonia is widely regarded as an attractive carrier because it can be stored as a liquid at comparatively high temperatures compared to $\mathrm{LH} 2$, and there is considerable experience with handling and transporting it as a liquid. On the other hand, ammonia is toxic and has a pungent odour and requires careful management [23]. Ammonia is produced at a significant scale today using the Haber Bosch process, primarily using natural gas as the hydrogen source with nitrogen produced from air using cryogenic means or pressure swing adsorption [42]. Although the reaction is exothermic $(\Delta \mathrm{H}=-46 \mathrm{~kJ} / \mathrm{mol}$ ammonia or 
$-30.6 \mathrm{~kJ} / \mathrm{mol} \mathrm{H}_{2}$ ), and should be favoured by low temperatures and pressures, the kinetics of the reaction mean that in practice the process is conducted at high pressures and high temperatures $\left(450{ }^{\circ} \mathrm{C}, 200 \mathrm{bar}\right)$ in the presence of an iron oxide based catalyst [42]. The reaction is also characterised by low conversion per pass and considerable gas separation and recycle requirements [43].

One of the challenges in evaluating the energy efficiency of ammonia as a hydrogen carrier is that the application becomes extremely important. Many of the intended applications based on current generation fuel cells will require high purity hydrogen, although Japan is also exploring the direct use of ammonia in fuel cells and gas turbines for power generation. The associated difficulty is that the basis for the analysis must be carefully considered, as it becomes important to be clear if we are considering the energy content of a tonne of ammonia or the energy content of the contained hydrogen. The "energy content of the contained hydrogen" is of course somewhat ambiguous as it could refer to the energy of the hydrogen used to synthesise the ammonia, or it could refer to the net energy content of the hydrogen that would be produced from decomposing or cracking the ammonia. Even more simplistic would be the view that the energy content is the LHV of the weight of the contained hydrogen-although it is clear on reflection that this is not a valid view and that the LHV of the ammonia is a more appropriate calorific value.

The total energy consumption for producing ammonia from renewable energy using electrolysis and Haber Bosch synthesis is not well characterised since there are no operating plants, but has been suggested to be in the range of 10 to $12 \mathrm{kWh} / \mathrm{kg}$ ammonia [44-47]. Several studies have suggested that it is possible to use the exothermic heat of reaction to maintain the required process conditions and provide the electrical inputs [43,47]. It is also worth reflecting on the maximum amount of energy that could be retained if all the hydrogen could be converted to ammonia without additional energy input. The LHV efficiency of the synthesis process can be defined as

$$
\text { LHV efficiency }=\left(\mathrm{M}_{\mathrm{NH} 3} \times \mathrm{LHV}_{\mathrm{NH} 3}\right) /\left(\mathrm{M}_{\mathrm{H} 2} \times \mathrm{LHV}_{\mathrm{H} 2}\right),
$$

and substituting the stoichiometric yield of $5.63 \mathrm{~kg}$ of ammonia per $\mathrm{kg}$ of hydrogen in Equation (2) results in an LHV efficiency of $87.3 \%$ for $100 \%$ conversion. This assumes, of course, that all the heat of the reaction could be recovered and would be sufficient to provide the electrical duties for the ammonia synthesis plant.

James and van Delft [47] examined the energy efficiency of various hydrogen production options and estimated a specific energy demand of $9.5 \mathrm{kWh}$ per $\mathrm{kg}$ of $\mathrm{NH}_{3}$ when hydrogen was produced using a PEM electrolyser, although compression and liquefaction were not discussed. They found that the ammonia synthesis process could operate without external heat input and required only cooling water and small amounts of cryogenic duty. Assuming the electrolyser is 70\% efficient, the minimum requirement for electrical energy for electrolysis is $8.5 \mathrm{kWh} / \mathrm{kg}$ of ammonia, based on $100 \%$ conversion of hydrogen to ammonia. This would leave an additional demand of $1 \mathrm{kWh} / \mathrm{kg}$ of ammonia for other duties in the plant and for hydrogen and ammonia losses in purge streams, suggesting a hydrogen conversion efficiency of $89.5 \%$ and a requirement of $1.12 \mathrm{~kg}$ of hydrogen per $\mathrm{kg}$ of ammonia. This equates to an LHV efficiency of hydrogen to ammonia of $78.1 \%$ using Equation (2).

Aziz et al. also examined the synthesis of ammonia using a flowsheet that integrated ammonia and electricity production from a renewable hydrogen stream, and concluded that the plant could operate with a small surplus of electricity [43]. The highest achievable LHV efficiency for simulations of the conversion of hydrogen to ammonia was $66.69 \%$, with surplus power generation of $0.23 \%$. A simple mass balance on this process confirms that the hydrogen conversion efficiency is lower than predicted by James and van Delft, although the latter did not present details of their modelling [47]. Substitution of the LHV efficiency from Aziz et al. into Equation (2) indicates that the yield of ammonia is $4.30 \mathrm{~kg}$ per $\mathrm{kg}$ of hydrogen consumed. The stoichiometric yield is $5.63 \mathrm{~kg}$ of ammonia, indicating that the actual requirement for synthesis of $5.63 \mathrm{~kg}$ of ammonia (containing 
$1 \mathrm{~kg}$ of hydrogen) is $1.31 \mathrm{~kg}$ of hydrogen. Assuming an electrolysis efficiency of $70 \%$, this corresponds to $62.3 \mathrm{kWh}$ of electricity, or $11.1 \mathrm{kWh} / \mathrm{kg}$ of ammonia.

Obara [48] also considered the energy flows for the production and transport of hydrogen as ammonia and MCH. Assuming 90\% conversion of hydrogen to ammonia, an energy flow of $34.5 \mathrm{~W}$ of ammonia was produced from $65 \mathrm{~W}$ of hydrogen at an LHV conversion efficiency of $53 \%$, with the bulk of the energy loss associated with hydrogen compression (19 W for compression and $11.5 \mathrm{~W}$ for ammonia synthesis and cryogenic air separation). The low efficiency is possibly a reflection of the ammonia reactor conditions, which were assumed to be 350 bar and $500{ }^{\circ} \mathrm{C}$ (perhaps to achieve a high single pass conversion). Equation (2) can be used to show that this implies a consumption of $1.64 \mathrm{~kg}$ of hydrogen per $\mathrm{kg}$ of ammonia, equivalent to $13.9 \mathrm{kWh} / \mathrm{kg}$ ammonia.

It is clear there is a lack of consensus on the efficiency of ammonia synthesis from hydrogen, as the analysis of various literature sources above has yielded widely varying LHV efficiencies of $53.1 \%, 66.7 \%$, and $78.1 \%$, and corresponding energy consumptions of $13.9,11.1$, and $9.5 \mathrm{kWh} / \mathrm{kg}$ ammonia. In this study we will assume that the $11.1 \mathrm{kWh} / \mathrm{kg}$ ammonia established by Aziz et al. is a reasonable estimate, as it has the most comprehensive simulation as published and sits within the expected range of $10-12 \mathrm{kWh} / \mathrm{kg}$. This results in an energy efficiency of conversion of RE to ammonia in country of $46.7 \%$ on an LHV basis (c.f. $57.8 \%$ for liquid hydrogen).

The energy for shipping liquid ammonia is expected to be similar to the IEA's energy intensity of global shipping of $0.08 \mathrm{MJ} / \mathrm{tkm}$, since it is expected that LPG carriers will be suitable [37]. Thus, over the travel distance from Bluff to Yokohama, the estimated energy demand for shipping is $0.9 \mathrm{GJ} / \mathrm{t}$ or $0.25 \mathrm{kWh} / \mathrm{kg}$ of ammonia, about $4.9 \%$ of the energy content of the cargo (LHV). This energy would conventionally be provided by fuel oil, but an alternative fuel will be needed for $\mathrm{CO}_{2}$ free supply chains. If the ship were powered by the ammonia cargo, the effective energy demand increases from $11.1 \mathrm{kWh}$ to $11.6 \mathrm{kWh} / \mathrm{kg}$ ammonia delivered (since the ammonia consumed was produced at an efficiency of $46.7 \%$ ), decreasing the LHV efficiency of the supply chain to $44.5 \%$ RE for delivered energy on arrival in Japan.

If hydrogen is required, the ammonia will need to be decomposed (cracked) to hydrogen and nitrogen. Ammonia cracking is endothermic and energy intensive, and the production of high purity hydrogen for fuel cells also requires scrubbing of the product gas to remove traces of ammonia that would otherwise poison catalysts in fuel cells [42]. It has been proposed that this can most efficiently be effected using catalytic metal membrane reactors operating at $400{ }^{\circ} \mathrm{C}$ [42]. The authors estimate the net energy required for ammonia cracking to be between 0.28 and $0.30 \mathrm{kWh} / \mathrm{kg}$ of ammonia, although $15 \%$ of the hydrogen cannot be recovered from the membrane reactor. This equates to a total energy loss of $1.41 \mathrm{kWh} / \mathrm{kg}$ of ammonia, or an overall cracker efficiency of $75.9 \%$. Additionally, if it is to be used in fuel cell vehicles, the hydrogen also needs to be compressed to 880 bar to enable rapid filling of the storage tanks. The authors estimate compression losses of 0.5 to $0.67 \mathrm{kWh} / \mathrm{kg}$ of ammonia, which corresponds to a compression efficiency of $88.0 \%$. The net efficiency of cracking and compression is therefore $66.8 \%$, which would result in an overall efficiency of $31.2 \%$ of RE to compressed hydrogen suitable for automotive fuel cell applications. Obara [48] also considered a system in which ammonia was dissociated and compressed, but only for use in a SOFC and not for use in FCVs. This analysis also assumed that the energy for dissociation was provided as $7.5 \mathrm{~W}$ of thermal energy (potentially recuperated from the SOFC) added to $42 \mathrm{~W}$ of chemical energy in the hydrogen to yield $35.5 \mathrm{~W}$ of hydrogen fuel for the SOFC, yielding an overall efficiency of $71.7 \%$ for cracking and compression, slightly higher than the study by Giddey et al. [42].

The energy efficiency of the different steps along the ammonia supply chain is summarised in Table 5. The efficiency depends greatly on whether the ammonia is used directly or needs to be converted to hydrogen. We have assumed that the cracking and compression process consumes $30 \%$ of the LHV energy. It should also be noted that it is a little confusing to talk in terms of the energy intensity of the hydrogen (or ammonia) as the energy is 
carried by different molecules along the supply chain and enthalpy changes mean that the LHV efficiency is a more sensible metric. Nevertheless, Table 5 does attempt to draw out the energy intensity of each step as an indication of where the different areas of energy loss are occurring along the supply chain. For example, while the electrical energy required to produce the ammonia has been assumed to be $11.1 \mathrm{kWh} / \mathrm{kg}$ (i.e., $62.3 \mathrm{kWh} / \mathrm{kg}$ of contained hydrogen), the enthalpy loss and incomplete conversion of hydrogen in synthesis means that the effective energy consumption to this point is $71.4 \mathrm{kWh} / \mathrm{kg}$ when we consider the hydrogen fuel value.

Table 5. Summary of energy efficiency for the various stages in a liquid ammonia supply chain.

\begin{tabular}{|c|c|c|c|c|}
\hline Step & LHV Efficiency & $\begin{array}{l}\text { Energy Intensity, } \\
\mathrm{kWh} / \mathrm{kg} \mathrm{NH} \mathrm{NH}_{3}\end{array}$ & $\begin{array}{c}\text { Energy Intensity, } \\
\mathrm{kWh} / \mathrm{kg} \mathrm{H}\end{array}$ & $\begin{array}{c}\text { Retained Energy, } \\
\text { LHV (MWh) }\end{array}$ \\
\hline Generation & & & & 100 \\
\hline Electrolysis & $70.0 \%$ & 8.5 & 47.6 & 70 \\
\hline Formation & $66.7 \%$ & 2.6 & 23.8 & 46.7 \\
\hline Shipping & $95.3 \%$ & 0.54 & 3.5 & $44.5^{1}$ \\
\hline Release $^{2}$ & $70.0 \%$ & 5.0 & 32.1 & 31.2 \\
\hline Total & $31.2 \%$ & 16.6 & 107.0 & \\
\hline LHV (kWh/kg) & & 5.17 & 33.33 & \\
\hline
\end{tabular}

${ }^{1}$ If ammonia is used directly as a fuel, then the supply chain efficiency increases to $44.5 \%{ }^{2}$ Assumes that this energy is sourced from the fuel itself as opposed to an external source.

\section{3. $\mathrm{MCH}$}

Organic carriers have also been extensively studied for hydrogen transport due to their ability to store hydrogen with excellent stability as liquids over a wide range of temperatures [49-51]. The Japanese SIP program selected the toluene-methyl cyclohexane $(\mathrm{MCH})$ system for investigation, and the Chiyoda Corporation has been prominent in promoting this technology, having demonstrated the processes of hydrogenation and dehydrogenation at pilot scale [52]. The reaction of hydrogen with toluene can be conducted at a temperature of $120^{\circ} \mathrm{C}$ and a pressure of about $30 \mathrm{bar}$ in the presence of a catalyst [53]. The reaction is strongly exothermic and releases $68.3 \mathrm{~kJ} / \mathrm{mol}$ of $\mathrm{H}_{2}$. Aziz et al. suggest that the exothermic heat of reaction can be used to generate steam for electricity generation, although this was in the context of an integrated plant for the drying and gasification of brown coal for the production of hydrogen in the form of $\mathrm{MCH}$ [51].

Wijayanta et al. [23] estimate that the production efficiency of $\mathrm{MCH}$ is around $85 \%$ "considering both theoretical efficiency of the reaction, exergy loss, and compression work during hydrogenation"; Aziz et al. [24] suggest that the efficiency of production can be as high as $95 \%$. However, there must be an enthalpy loss associated with an exothermic reaction. The enthalpy of formation of gaseous and liquid water at STP is -241.83 and $-285.83 \mathrm{~kJ} / \mathrm{mol}$, respectively [54], placing an upper boundary on the energetic conversion efficiency of $71.8 \%$ (LHV basis) to $76.1 \%$ (HHV basis) if we simply reduce the available enthalpy by the heat of reaction for $\mathrm{MCH}$ formation. Note that this is more complicated than in the case of ammonia, as the heat of combustion is not in fact relevant for $\mathrm{MCH}$ as it is a carrier rather than a potential final fuel. Regardless, it is unlikely that the enthalpy loss of $\mathrm{MCH}$ formation can be efficiently converted to electricity due to the low temperature of the reaction. This implies that the synthesis of $\mathrm{MCH}$ from toluene will result in a significant energy penalty, probably borne by the exporting country, reducing the energy content of the exported hydrogen significantly. Indeed, the heat release in carrier formation is more than twice that of ammonia per mol of hydrogen, although the process itself will consume less electricity as it is much less stringent in terms of process conditions with high single pass conversion at moderate temperature and pressure.

Scherer et al. [55] considered the use of $\mathrm{MCH}$ for seasonal storage of electricity and assessed the efficiency for the formation of $\mathrm{MCH}$ from $\mathrm{RE}$ over summer and winter and the production of electricity from the stored energy in winter using an SOFC, MCFC, or a gas turbine. While the summer synthesis efficiency was not reported, it can be back calculated from the overall efficiency to be from 71.7 to $73.5 \%$, which seems anomalously 
high as it includes both electrolysis and synthesis steps. Obara [48] conducted an energy and exergy analysis of the $\mathrm{MCH}$ system and concluded that the $\mathrm{MCH}$ formation process was about $65 \%$ efficient on a retained energy basis. If we assume that the additional energy requirement can be treated as an energy penalty on top of the electrolyser demand, the indicative energy consumption to produce hydrogen as $\mathrm{MCH}$ is $73.2 \mathrm{kWh} / \mathrm{kg}$ of hydrogen (noting that this is not strictly realistic given additional energy is required to release the hydrogen from the $\mathrm{MCH}$ ).

Shipping of $\mathrm{MCH}$ is relatively straightforward as it is possible to use existing tankers. We can therefore assume that the IEA global shipping intensity will apply to the $\mathrm{MCH}$, giving an energy consumption over the voyage of $0.91 \mathrm{GJ} / \mathrm{t}$ as with ammonia. However, $\mathrm{MCH}$ is the lowest of the carriers in terms of hydrogen density at just 6.16 weight $\%$, and thus the energy for shipping amounts to $4.2 \mathrm{kWh} / \mathrm{kg}$ of hydrogen.

Dissociation of $\mathrm{MCH}$ would take place in the importing country, and unlike ammonia is essential prior to any downstream applications. Furthermore, the hydrogen requires purification to ensure that $\mathrm{MCH}$ carryover is minimised. The most efficient option would be to integrate waste heat from hydrogen utilization with the decomposition of the $\mathrm{MCH}$. Scherer et al. [55] examined a scenario where waste heat from an SOFC was used for $\mathrm{MCH}$ decomposition, and concluded that the net efficiency of the conversion of the stored energy to electricity could be $55 \%$, although this was based on an SOFC direct current efficiency of $61 \%$. Obara [48] used a more conservative SOFC efficiency of $50 \%$, and also considered power conditioning and other losses to arrive at an efficiency of $34.5 \%$ for $\mathrm{MCH}$ to exported power. A lower efficiency can be expected if the dehydrogenation and power generation are not integrated. The efficiency of dehydrogenation and compression can be estimated from Obara's energy flows: $10 \mathrm{~W}$ of thermal energy is added to $42 \mathrm{~W}$ of bound chemical energy as $\mathrm{MCH}$ to yield $33.5 \mathrm{~W}$ of hydrogen fuel for the SOFC at an overall efficiency of $64.4 \%$.

Table 6 summarises the energy efficiency of the different steps along the supply chain for $\mathrm{MCH}$. Note that, as with ammonia, the "energy intensity column" is indicative only and estimates the energy consumed in each step, including the effect of enthalpy changes as the carrier molecule changes.

Table 6. Summary of energy efficiency for the various stages in an $\mathrm{MCH}$ hydrogen supply chain.

\begin{tabular}{|c|c|c|c|}
\hline Step & LHV Efficiency & $\begin{array}{c}\text { Energy Intensity, } \\
\mathrm{kWh} / \mathrm{kg} \mathrm{H} \mathrm{H}_{2}\end{array}$ & $\begin{array}{l}\text { Retained Energy, } \\
\text { LHV (MWh) }\end{array}$ \\
\hline Generation & & & 100 \\
\hline Electrolysis & $70.0 \%$ & 47.6 & 70 \\
\hline Formation & $65.0 \%$ & 25.6 & 45.5 \\
\hline Shipping & $94.6 \%$ & 4.2 & 43.0 \\
\hline Release $^{1}$ & $64.4 \%$ & 42.8 & 27.7 \\
\hline Total & $27.7 \%$ & 120.2 & \\
\hline
\end{tabular}

Efficiency of energy production can potentially be increased with integration of heat from SOFC.

\section{Discussion and Conclusions}

The energy intensity and retained energy for the three prospective carriers from Tables 4-6 are presented in Figures 3 and 4. Liquid hydrogen has the lowest energy consumption for formation as well as the lowest shipping losses for a hypothetical supply chain from Bluff in New Zealand to Yokohama in Japan, assuming the Kawasaki Heavy Industries target of $0.2 \%$ per day boil off can be achieved and this hydrogen is sufficient to provide the energy for propulsion. LH2 is also the only carrier of the three considered here with the potential for additional energy production in Japan from the release of hydrogen through recovery of part of the liquefaction energy. However, it is important to note that LH2 bulk carriers are still in the concept phase and the technology is not currently available. 


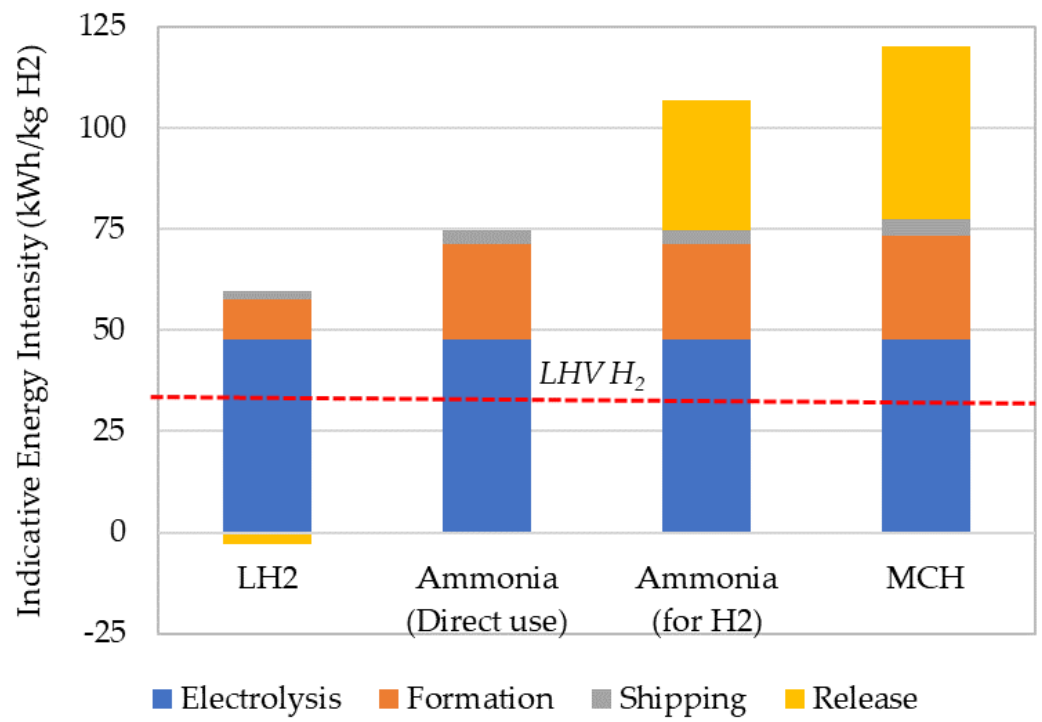

Figure 3. Indicative energy intensity of hydrogen carriers (data from Tables 4-6).

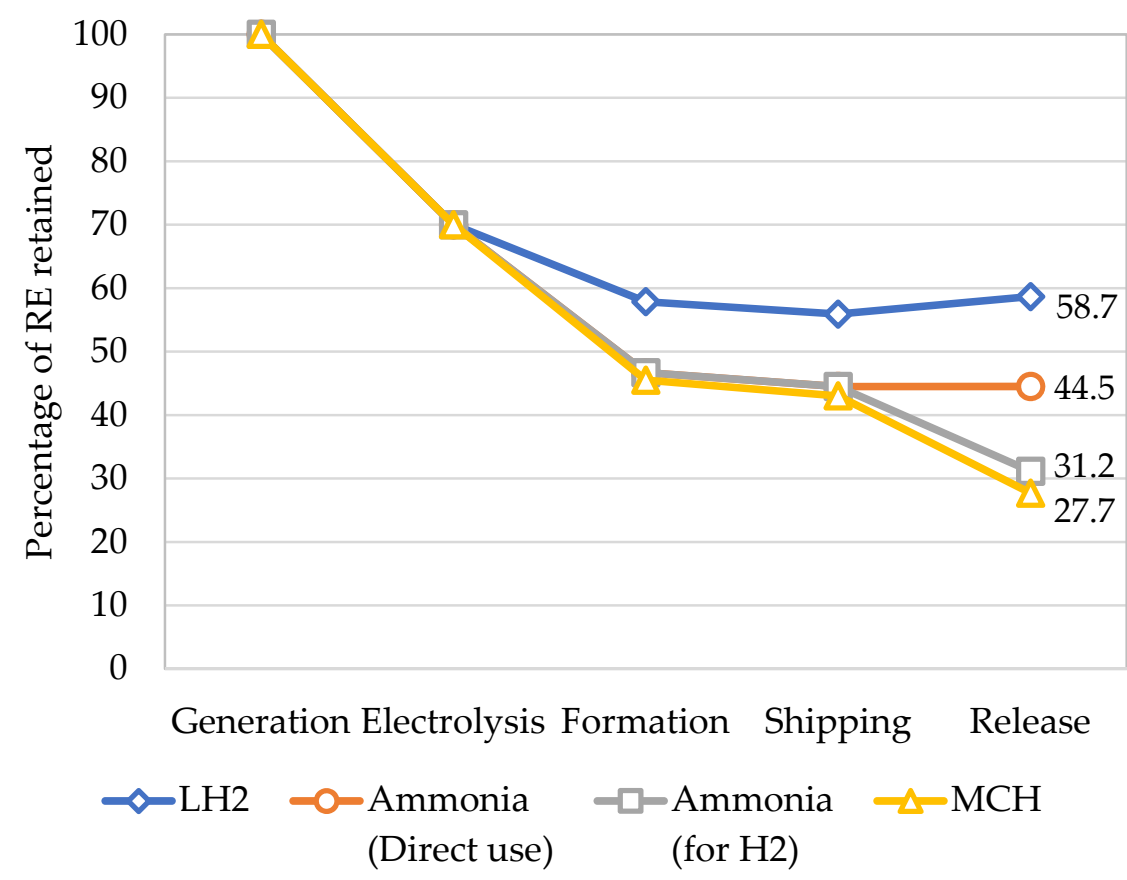

Figure 4. Amount of RE energy retained at stages along the supply chain from Bluff to Yokohama (data from Tables 4-6).

While it could also be argued that the assumption of $10 \mathrm{kWh} / \mathrm{kg}$ assumed for LH2 is a little optimistic, it is nevertheless clear that the energy associated with carrier formation is likely to be significantly higher for both ammonia and $\mathrm{MCH}$. In the case of ammonia, this is a consequence of both the lower calorific value of ammonia as a fuel compared to the quantity of contained hydrogen, plus additional losses associated with incomplete conversion and the energy demands of operating a high temperature process that has a relatively low conversion per pass and high gas separation and recycle duties. On the other hand, ammonia is capable of being transported using existing infrastructure, and if it can be used directly then arguably this is a carrier that can be used now, whereas LH2 will require significant investment in new shipping infrastructure before it can be considered a viable shipping option.

The case for ammonia-and also for $\mathrm{MCH}$ - is less certain if hydrogen is the desired energy vector in Japan. In both cases, the energy required for dehydrogenation is a 
significant energy penalty with only around $30 \%$ of the initial renewable energy retained as hydrogen energy. This analysis assumed that the energy required for dissociation was provided by the hydrogen itself, and it is possible that there are alternative sources of energy available, including potentially the waste heat from solid oxide fuel cells. However, if the end use application is fuel cell vehicles then the energy associated with cracking, clean up, and compression to sufficient purity and pressure will be significant.

More broadly, for truly "green hydrogen" and zero emissions energy, the energy consumption at all stages in the supply chain will need to be supplied by zero-carbon sources. In this analysis, we have assumed that the energy requirements have effectively been provided by adding additional renewable energy to the input side, effectively increasing the amount of hydrogen produced by the exporting country to provide an amount of energy to the importing country. Given that the importing country is energy deficient (almost by definition), this may prove challenging but the co-location of utilization and dehydrogenation processes-such as the example of $\mathrm{MCH}$ decomposition coupled with SOFC electricity production-could improve overall energy supply chain efficiencies.

In summary, it remains difficult to say with certainty which hydrogen carrier is going to dominate from an energy perspective, and it is likely that multiple carriers will be used over time. Ammonia has significant advantages in the short to medium term due to its comparative familiarity and ease of handling with existing infrastructure. However, liquid hydrogen appears to offer a number of advantages over ammonia including higher supply chain efficiency and ease of meeting fuel cell application purity requirements. On the other hand, the supply chain is as yet in a relatively early stage of development with only a single prototype vessel constructed. $\mathrm{MCH}$ appears to have a challenging road to implementation as the enthalpy of dehydrogenation cannot be avoided through direct use applications as is possible with ammonia. Against this, handling of the carrier itself is the least challenging of the three options, and the capital cost of $\mathrm{MCH}$ synthesis and decomposition is likely to be significantly less than that for hydrogen liquefaction or ammonia synthesis. All carriers have the issue of vessels returning to the exporting country with no payload, although in the case of $\mathrm{MCH}$ this is associated with the transport of toluene, which may lead to slightly higher overall shipping emissions (the return voyage was not considered in this analysis). Ultimately, it is the delivered cost of hydrogen that will determine which carriers will be used, and this will depend on a combination of infrastructure availability, energy efficiency, and capital and operating costs.

Funding: This research received no external funding.

Institutional Review Board Statement: Not applicable.

Informed Consent Statement: Not applicable.

Conflicts of Interest: The author declares no conflict of interest.

\section{References}

1. BP. Statistical Review of World Energy, 2020 - 69th Edition. 2020. Available online: https://www.bp.com/content/dam/bp/ business-sites/en/global/corporate/pdfs/energy-economics/statistical-review /bp-stats-review-2020-full-report.pdf (accessed on 8 February 2021).

2. Rosen, M.A.; Koohi-Fayegh, S. The prospects for hydrogen as an energy carrier: An overview of hydrogen energy and hydrogen energy systems. Energy Ecol. Environ. 2016, 1, 10-29. [CrossRef]

3. IEA. The Future of Hydrogen for G20. Seizing Today's Opportunities; Report Prepared by IEA for the G20, Japan; IEA: Paris, France, 2019. Available online: https://static1.squarespace.com/static/5c350d6bcc8fedc9b21ec4c5/t/5e968939e89b9e37585b8134/15869238 83881/IEA+-+The_Future_of_Hydrogen.pdf (accessed on 18 June 2021).

4. Government of Japan Strategic Energy Plan. Available online: http:/ /www.enecho.meti.go.jp/en/category/others/basic_plan/ pdf/4th_strategic_energy_plan.pdf (accessed on 1 January 2018).

5. MOTIE. Announcement of Hydrogen Economy Roadmap. (In Korean). Available online: http://www.motie.go.kr/common/ download.do?fid=bbs\&bbs_cd_n=81\&bbs_seq_n=161262\&file_seq_n=2 (accessed on 7 May 2021).

6. Cross-Ministerial Strategic Innovation Promotion Program (SIP); Energy Carriers; Japan Science and Technology Agency (JST): Tokyo, Japan, 2016. Available online: https://www.jst.go.jp/sip/pdf/SIP_energycarriers2015_en.pdf (accessed on 18 June 2021). 
7. Climate Change Response (Zero Carbon) Amendment Bill 136-3 (2019), Government Bill Contents-New Zealand Legislation. Available online: https:/ / www.legislation.govt.nz/bill/government/2019/0136/latest/LMS183736.html (accessed on 27 July 2021).

8. $\quad$ MBIE. A Vision for Hydrogen in New Zealand; MBIE: Wellington, New Zealand, 2019.

9. POAL. Ports of Auckland to Build Auckland's First Hydrogen Production and Refuelling Facility. Available online: https: / / www.poal.co.nz/media/ports-of-auckland-to-build-auckland $\backslash$ T1 $\backslash$ textquoterights-first-hydrogen-production-andrefuelling-facility (accessed on 27 July 2021).

10. Hydrogen Energy-Tuaropaki Trust. Available online: http://www.tuaropaki.com/our-business/hydrogen-energy/ (accessed on 27 July 2021).

11. Hydrogen Refuelling Network. Hiringa Energy. Available online: https:/ / www.hiringa.co.nz/refuelling-network (accessed on 27 July 2021).

12. Hiringa Energy \& Ballance Agri-Nutrients. Green Urea Project. Available online: https://www.greenhydrogennz.com/ (accessed on 27 July 2021).

13. Southern Green Hydrogen. Available online: https:/ / www.southerngreenhydrogen.co.nz/ (accessed on 27 July 2021).

14. Contact Energy; Meridian Energy; McKinsey \& Company. The New Zealand Hydrogen Opportunity-A Perspective on New Zealand's Potential Role in the Emerging Global Hydrogen Economy; Contact Energy and Meridian Energy: Wellington, New Zealand, 2021. Available online: https:/ / www.datocms-assets.com/49051/1626295071-the-nz-hydrogen-opportunity.pdf (accessed on 30 July 2021).

15. METI. Summary of the Strategic Road Map for Hydrogen and Fuel Cells. Available online: http://www.meti.go.jp/english/ press/2014/pdf/0624_04a.pdf (accessed on 6 August 2021).

16. Li, H.-W.; Nishimiya, N. Insight from Japan's Hydrogen Strategy and Activities. Engineering 2021, 7, 722-725. [CrossRef]

17. Popov, S.; Baldynov, O. The Hydrogen Energy Infrastructure Development in Japan. In Proceedings of the International Conference Green Energy and Smart Grids (GESG 2018), Cape Hadartha, Russia, 27 July-2 August 2018; Volume 69, p. 02001. [CrossRef]

18. Chapman, A.J.; Fraser, T.; Itaoka, K. Hydrogen import pathway comparison framework incorporating cost and social preference: Case studies from Australia to Japan. Int. J. Energy Res. 2017, 41, 2374-2391. [CrossRef]

19. METI (Ministry of Energy Trade and Industry). Basic Hydrogen Strategy (Key Points). Available online: https:/ / www.meti.go. jp/english/press/2017/pdf/1226_003a.pdf (accessed on 20 May 2021).

20. Matsumoto, A. An Industrial Perspective on Business Potential of Solar Hydrogen. Available online: https://www.astri.org.au/ wp-content/uploads /2014/11/ASTRI-20160502-0950-Ayako_Matsumoto-Mitsui.pdf (accessed on 26 May 2021).

21. Heuser, P.M.; Ryberg, D.S.; Grube, T.; Robinius, M.; Stolten, D. Techno-economic analysis of a potential energy trading link between Patagonia and Japan based on $\mathrm{CO}_{2}$ free hydrogen. Int. J. Hydrogen Energy 2019, 44, 12733-12747. [CrossRef]

22. Ishimoto, Y.; Kurosawa, A.; Sasakuram, M.; Sakata, K. Study of demand for $\mathrm{CO}_{2}$ free hydrogen in Japan and the world. J. Jpn. Inst. Energy 2015, 94, 170-176. [CrossRef]

23. Wijayanta, A.T.; Oda, T.; Purnomo, C.W.; Kashiwagi, T.; Aziz, M. Liquid hydrogen, methylcyclohexane, and ammonia as potential hydrogen storage: Comparison review. Int. J. Hydrogen Energy 2019, 44, 15026-15044. [CrossRef]

24. Aziz, M.; Oda, T.; Kashiwagi, T. Comparison of liquid hydrogen, methylcyclohexane and ammonia on energy efficiency and economy. Energy Procedia 2019, 158, 4086-4091. [CrossRef]

25. Shiozawa, B. SIP "Energy Carriers" and Potential of Ammonia-A Door Opener of a Low Carbon Society; Cabinet Office of Japanese Government: Tokyo, Japan, 2018. Available online: http://h2est.ee/wp-content/uploads/2018/09/ammonia_as_hydrogen_ carrier_Bunro_Ahiozawa_2018-09-04.pdf (accessed on 18 June 2021).

26. Mørch, C.S.; Bjerre, A.; Gøttrup, M.P.; Sorenson, S.C.; Schramm, J. Ammonia/hydrogen mixtures in an SI-engine: Engine performance and analysis of a proposed fuel system. Fuel 2011, 90, 854-864. [CrossRef]

27. Reuß, M.; Grube, T.; Robinius, M.; Preuster, P.; Wasserscheid, P.; Stolten, D. Seasonal storage and alternative carriers: A flexible hydrogen supply chain model. Appl. Energy 2017, 200, 290-302. [CrossRef]

28. Schiebahn, S.; Grube, T.; Robinius, M.; Tietze, V.; Kumar, B.; Stolten, D. Power to gas: Technological overview, systems analysis and economic assessment for a case study in Germany. Int. J. Hydrogen Energy 2015, 40, 4285-4294. [CrossRef]

29. Kamiya, S.; Nishimura, M.; Harada, E. Study on introduction of $\mathrm{CO}_{2}$ free energy to Japan with liquid hydrogen. Phys. Procedia 2015, 67, 11-19. [CrossRef]

30. Krasae-in, S.; Stang, J.H.; Neksa, P. Development of large-scale hydrogen liquefaction processes from 1898 to 2009. Int. J. Hydrogen Energy 2010, 35, 4524-4533. [CrossRef]

31. Watanabe, T.; Murata, K.; Kamiya, S.; Ota, K.-I. Cost estimation of transported hydrogen, produced by overseas wind power generations. In Proceedings of the 18th World Hydrogen Energy Conference 2010—WHEC 2010 Parallel Sessions Book 3: Hydrogen Production Technologies_Part 2; Stolten, D., Grube, T., Eds.; Forschungszentrum Julich GmbH, Zentralbibliothek: Julich, Germany, 2010; pp. 547-557.

32. Ohlig, K.; Decker, L. The latest developments and outlook for hydrogen liquefaction technology. AIP Conf. Proc. 2014, 1573, 1311-1317. [CrossRef]

33. Cardella, U.; Decker, L.; Klein, H. Economically viable large-scale hydrogen liquefaction. IOP Conf. Ser. Mater. Sci. Eng. 2017, 171, 012013. [CrossRef] 
34. Nexant, I.; Air Liquide; Argonne National Laboratory, C.T.V.; Technology, G.; Pacific Northwest National Laboratory; TIAX LLC. H2A Hydrogen Delivery Infrastructure Analysis Models and Conventional Pathway Options Analysis Results; Nexant, Inc.: 2008. Available online: https://www.energy.gov/sites/default/files/2014/03/f9/nexant_h2a.pdf (accessed on 22 June 2021).

35. Stolzenburg, K.; Mubbala, R. Integrated Design for Demonstration of Efficient Liquefaction of Hydrogen (IDEALHY); Hydrogen Liquefaction Report; FCH JU: Brussels, Belgium, 2013. Available online: https:/ /www.idealhy.eu/uploads/documents/IDEALHY_D3 -16_Liquefaction_Report_web.pdf (accessed on 22 June 2021).

36. Kawasaki World's First Liquefied Hydrogen Carrier SUISO FRONTIER Launches Building an International Hydrogen Energy Supply Chain Aimed at Carbon-free Society. Kawasaki Heavy Industries, Ltd. Available online: https://global.kawasaki.com/ en/corp/newsroom/news/detail/?f=20191211_3487 (accessed on 22 June 2021).

37. Ishimoto, Y.; Voldsund, M.; Nekså, P.; Roussanaly, S.; Berstad, D.; Gardarsdottir, S.O. Large-scale production and transport of hydrogen from Norway to Europe and Japan: Value chain analysis and comparison of liquid hydrogen and ammonia as energy carriers. Int. J. Hydrogen Energy 2020, 45, 32865-32883. [CrossRef]

38. IEA. Energy Intensity of International Shipping under EEDI and Sustainable Development Scenario, 2005-30-Charts-Data \& Statistics. Available online: https: / / www.iea.org/data-and-statistics/charts/energy-intensity-of-international-shipping-undereedi-and-sustainable-development-scenario-2005-30 (accessed on 22 June 2021).

39. Le, S.; Lee, J.Y.; Chen, C.L. Waste cold energy recovery from liquefied natural gas (LNG) regasification including pressure and thermal energy. Energy 2018, 152, 770-787. [CrossRef]

40. Atienza-Márquez, A.; Bruno, J.C.; Coronas, A. Cold recovery from LNG-regasification for polygeneration applications. Appl. Therm. Eng. 2018, 132, 463-478. [CrossRef]

41. Zhang, N.; Lior, N. A novel Brayton cycle with the integration of liquid hydrogen cryogenic exergy utilization. Int. J. Hydrogen Energy 2008, 33, 214-224. [CrossRef]

42. Giddey, S.; Badwal, S.P.S.; Munnings, C.; Dolan, M. Ammonia as a Renewable Energy Transportation Media. ACS Sustain. Chem. Eng. 2017, 5, 10231-10239. [CrossRef]

43. Aziz, M.; Putranto, A.; Biddinika, M.K.; Wijayanta, A.T. Energy-saving combination of N2 production, NH3 synthesis, and power generation. Int. J. Hydrogen Energy 2017, 42, 27174-27183. [CrossRef]

44. ISPT. Power to Ammonia: Feasibility Study for the Value Chains and Business Cases to Produce CO2-Free Ammonia Suitable for Various Market Applications; Report; Institute for Sustainable Process Technology: Amersfoort, The Netherlands, 2017. Available online: https:/ / www.topsectorenergie.nl/sites/default/files/uploads/Energie\%20en\%20Industrie/Power\%20to\%20Ammonia\% 202017.pdf (accessed on 22 June 2021).

45. Brown, T. Ammonia Technology Portfolio: Optimize for Energy Efficiency and Carbon Efficiency-Ammonia Industry. Available online: https: / / ammoniaindustry.com/ammonia-technology-portfolio-optimize-for-energy-efficiency-and-carbon-efficiency / (accessed on 22 June 2021).

46. Rouwenhorst, K.H.R.; Van der Ham, A.G.J.; Mul, G.; Kersten, S.R.A. Islanded ammonia power systems: Technology review \& conceptual process design. Renew. Sustain. Energy Rev. 2019, 114, 109339.

47. James, J.D.; van Delft, Y.C. Power to Ammonia Process Options: Input to Power to Ammonia Value Chains and Business Cases; ECN: Petten, The Netherlands, 2017. Available online: http:/ / resolver.tudelft.nl/uuid:3be645b6-30e2-45cf-afbc-23b1e4acb7ea (accessed on 10 August 2021).

48. Obara, S. Energy and exergy flows of a hydrogen supply chain with truck transportation of ammonia or methyl cyclohexane. Energy 2019, 174, 848-860. [CrossRef]

49. Taube, M.; Rippin, D.W.T.; Cresswell, D.L.; Knecht, W. A system of hydrogen-powered vehicles with liquid organic hydrides. Int. J. Hydrogen Energy 1983, 8, 213-225. [CrossRef]

50. Klvana, D.; Chaouki, J.; Kusohorsky, D.; Chavarie, C.; Pajonk, G.M. Catalytic storage of hydrogen: Hydrogenation of toluene over a nickel/silica aerogel catalyst in integral flow conditions. Appl. Catal. 1988, 42, 121-130. [CrossRef]

51. Aziz, M.; Zaini, I.N.; Oda, T.; Morihara, A.; Kashiwagi, T. Energy conservative brown coal conversion to hydrogen and power based on enhanced process integration: Integrated drying, coal direct chemical looping, combined cycle and hydrogenation. Int. J. Hydrogen Energy 2017, 42, 2904-2913. [CrossRef]

52. Okada, Y.; Shimura, M. Development of large-scale H2 storage and transportation technology with Liquid Organic Hydrogen Carrier (LOHC). In Proceedings of the 21st Joint GCC-Japan Environment Symposium, Doha, Qatar, 5-6 February 2013. Available online: https:/ / www.jccp.or.jp/international/conference/docs/15rev-chiyoda-mr-shimura-chiyoda-h2-sturage-and-transpor. pdf (accessed on 28 June 2021).

53. Niermann, M.; Beckendorff, A.; Kaltschmitt, M.; Bonhoff, K. Liquid Organic Hydrogen Carrier (LOHC)—Assessment based on chemical and economic properties. Int. J. Hydrogen Energy 2019, 44, 6631-6654. [CrossRef]

54. Cox, J.D.; Wagman, D.D.; Medvedev, V.A. CODATA Key Values for Thermodynamics; Hemisphere Publishing Corp.: New York, NY, USA, 1984.

55. Scherer, G.W.H.; Newson, E.; Wokaun, A. Economic analysis of the seasonal storage of electricity with liquid organic hydrides. Int. J. Hydrogen Energy 1999, 24, 1157-1169. [CrossRef] 